\title{
Prophylactic Effects of Ethanolic Extract of Irvingia gabonensis Stem Bark against Cadmium-Induced Toxicity in Albino Rats
}

\author{
Oluwafemi Adeleke Ojo, ${ }^{1}$ Basiru Olaitan Ajiboye, ${ }^{1}$ \\ Babatunji Emmanuel Oyinloye, ${ }^{1}$ and Adebola Busola Ojo ${ }^{2}$ \\ ${ }^{1}$ Department of Chemical Sciences, Biochemistry Unit, Afe Babalola University, Ado-Ekiti, PMB 5454, Ekiti State, Nigeria \\ ${ }^{2}$ Department of Biochemistry, Ekiti State University, Ado-Ekiti, Ekiti State, Nigeria
}

Correspondence should be addressed to Oluwafemi Adeleke Ojo; oluwafemiadeleke08@gmail.com

Received 28 April 2014; Accepted 19 August 2014; Published 1 September 2014

Academic Editor: Hérida Salgado

Copyright ( 2014 Oluwafemi Adeleke Ojo et al. This is an open access article distributed under the Creative Commons Attribution License, which permits unrestricted use, distribution, and reproduction in any medium, provided the original work is properly cited.

The prophylactic effect of ethanolic extract of Irvingia gabonensis stem bark on cadmium-induced oxidative damage in male albino rats' liver was investigated. Male Wistar rats were divided into control, cadmium, and treatment groups. In the prophylactic experiment, Irvingia gabonensis (200 and $400 \mathrm{mg} / \mathrm{kg}$ body weight) was administered by oral gavage for 21 days before exposure to cadmium. Antioxidant marker enzymes such as reduced glutathione (GSH) levels, catalase (CAT), glutathione peroxidase (GPx), superoxide dismutase (SOD), and lipid peroxidation (LPO) were determined in the liver and heart alanine aminotransferase (ALT) and aspartate aminotransferase (AST) activities were monitored and histological examination was carried out. Results indicate that cadmium-induced rats had significantly increased relative weight of liver and heart when compared to controls. Treatment with Irvingia gabonensis at 200 and $400 \mathrm{mg} / \mathrm{kg}$ caused a significant decrease in relative weight of the organs. In cadmium-induced rats, serum ALT and AST activities and levels of LPO were increased whereas hepatic and cardiac marker enzymes significantly decreased. Furthermore, histological alteration in liver and aorta was observed in cadmium untreated rats and was ameliorated in cadmium rats treated with Irvingia gabonensis. In conclusion, the extract indicates antioxidant and hepatoprotective properties that eliminate the deleterious effects of toxic metabolites of cadmium.

\section{Introduction}

It has become obvious that humans have adjusted the global cycle of heavy metals and metalloids, including the toxic nonessential like cadmium. Thus there is enough opportunity for exposure to cadmium both inside and outside the workplace [1]. Cadmium (Cd) is one of the toxic hnavy metals and increased concentration of $\mathrm{Cd}$ in agricultural soils is to come from application of phosphate fertilizers, sewage sludge, waste water, and pesticides [2]. Further sources of cadmium drawn from mining at mines, smelting of ores, and industrial application of $\mathrm{Cd}$ in pigments, plastic stabilizers, and nickel cadmium batteries resulted in widespread agricultural soil pollution [3]. Cadmium is a risk reason for humans. It amasses in the body tissues, such as the liver, lungs, kidneys, bones, and reproductive organs $[4,5]$. Liu et al. [6] reported that $\mathrm{Cd}$ creates reactive oxygen species (ROS) causing oxidative damage in various tissues. It is shown that exposure to $\mathrm{Cd}$ by different routes causes increased lipid peroxidation (LPO) in membranes of erythrocytes and tissues, where thiobarbituric acid reactive substances (TBARS) and hydroperoxides are signs of oxidative damage [7-9]. Intakes of Cd indicates the use of glutathione (GSH) and protein binding sulfhydryl groups and thus improve the levels of free radicals, such as hydrogen peroxide, hydroxide, and superoxide anions [10]. The liver and kidney are the most vulnerable organs to $\mathrm{Cd}$ toxicity [11-14].

An increase in the levels of serum hepatic marker enzymes, such as aspartate aminotransferase (AST) and alanine transaminase (ALT) following Cd exposure, suggests the damaging effect of $\mathrm{Cd}$ on the liver in various studies $[15,16]$. Reyes et al. [17] and El-Sharaky et al. [18] reported that Cd nephrotoxicity resulted from producing frees radicals and by inducing cell necrosis and apoptosis. However, various changes in liver nonenzymatic antioxidants, for example GSH and liver enzymatic antioxidants, as superoxide dismutase 
(SOD) and Catalase (CAT), were associated with Cd exposure [19]. Herbal and natural products represent one of the common forms of complementary and alternative medicines [20]. They are available at supermarkets and pharmacies. As these products are without medical prescription, they must be safe for human health [21]. Many studies have shown the antioxidant properties of many natural products against toxic materials [22]. Irvingia gabonensis Baill. ex Lanen. (Irvingiaceae) is a commercial and indigenous fruit tree of West and Central Africa, which is identified as the most important tree for domestication [23, 24]. It is called bush mango in Nigeria. The plant occurs freely in many parts of Africa. Local names include goron biri (Hausa) and Ogbono (Ibo). The plant is a food supplement. The possible hepatoprotective effects of Irvingia gabonensis stem bark against Cdinduced hepatotoxicity is not reported so far. Therefore, in this study, we aimed to evaluate the hepatoprotective effect of the Irvingia gabonensis stem bark by using the Cd-induced subchronic oxidative toxicity in rats.

\section{Methods}

2.1. Chemicals. Cadmium chloride was bought from a local chemist in Ibadan, Nigeria. Thiobarbituric acids (TBA) were bought from Aldrich Chemical Co. (Milwaukee, WI, USA). Glutathione, hydrogen peroxide, 5,5'-dithios-bis-2nitrobenzoic acid (DNTB), and epinephrine were bought from Sigma Chemical Co., Saint Louis, MO, USA. Trichloroacetic acid (TCA) and thiobarbituric acid (TBA) was bought from British Drug House (BDH) Chemical Ltd., Poole, UK. Other reagents were of analytical grade and the purest quality available.

2.2. Collection and Extraction of Irvingia gabonensis Stem Bark. The stem bark of Irvingia gabonensis was collected in Ado-Ekiti (Ekiti State) and authenticated at the Department of Plant Science, Ekiti State University, Nigeria, and a voucher number (U.H.A.E 45) was deposited accordingly at the herbarium of Department of Plant Science, Ekiti State University. The stem bark of Irvingia gabonensis was airdried and crushed into fine powder. The powdered part was extracted with ethanol using maceration and the extract was concentrated in vacuum at $40^{\circ} \mathrm{C}$ with rotary evaporator and water bath to dryness. The yield of the extraction was 5.01\%.

2.3. Preliminary Phytochemical Screening. The preliminary phytochemical screening was carried out with ethanolic extracts of Irvingia gabonensis stem bark for the detection of various phytochemicals. Tests for common phytochemicals were carried out by standard methods [25].

2.4. Animals. Male Wistar rats (Rattus norvegicus) weighing between 80 and $120 \mathrm{~g}$ were bought from the animal house of the Department of Chemical Sciences, Biochemistry Unit, Afe Babalola University, Nigeria. Animals were kept in aired cages at room temperature $\left(28-30^{\circ} \mathrm{C}\right)$ and preserved on normal laboratory chow (Ladokun Feeds, Ibadan, Nigeria) and water ad libitum.
2.5. Induction of Experimental Animal. Cadmium was induced in groups II, III, and IV. Briefly, cadmium was dissolved in distilled water and after that managed by intravenous injection (through tail vein) at a dose of $4 \mathrm{mg} / \mathrm{kg}$ body weight.

\section{Study Design}

Twenty male rats were divided into four groups of five rats each. Group I served as the negative control and accessed normal rat diet and water ad libitum only; group II served as the positive control and was given $4 \mathrm{mg} / \mathrm{kg}$ body weight of cadmium chloride. Groups III and IV were given $200 \mathrm{mg} / \mathrm{kg}$ and $400 \mathrm{mg} / \mathrm{kg}$ body weight of the stem bark extracts after exposure to cadmium chloride, respectively.

3.1. Preparation of Tissues. Rats fasted overnight and were sacrificed 24 hours after the last dose of drugs. Liver and heart were removed and washed in ice-cold $1.15 \% \mathrm{KCl}$ solution, dried and weighed. A section of liver and aorta samples were fixed in $10 \%$ formalin for histological examination. The remaining parts of liver and heart were homogenized in 4 volumes of $50 \mathrm{mM}$ phosphate buffer, $\mathrm{pH} 7.4$, and centrifuged at $10,000 \mathrm{~g}$ for 15 minutes to get postmitochondrial supernatant fraction $(\mathrm{PMF})$. All procedures were carried out at temperature of $0-4^{\circ} \mathrm{C}$.

3.2. Preparation of Serum. Blood was collected from the heart of the animals into plain centrifuge tubes and allowed to stand for $1 \mathrm{hr}$. Serum was prepared by blood centrifugation at 3,000 rpm for 15 minutes in a Beckman bench centrifuge. The clear supernatant was used for estimating serum lipid profile and enzymes.

3.3. Biochemical Tests. Protein contents of the samples were tested by the method of Lowry et al. [26] using bovine serum albumin as standard. The alanine and aspartate aminotransferases (ALT and AST) were tested by the combined methods of Mohun and Cook [27] and Reitman and Frankel [28]. Lipid peroxidation level was tested by the reaction between 2-thiobarbituric acid (TBA) and malondialdehyde (MDA), a product of lipid peroxides as described by Buege and Aust [29]. The tissue superoxide dismutase (SOD) was measured by the nitro blue tetrazolium (NBT) decrease method of McCord and Fridovich [30]. Catalase (CAT) was tested spectrophotometrically by measuring the rate of decomposition of hydrogen peroxide at $240 \mathrm{~nm}$ as described by Aebi [31]. Reduced glutathione level was measured by the method of Beutler et al. [32], this method is based on the development of a relatively stable (yellow) colour when $5^{\prime}, 5^{\prime}$ dithiobis-(2-nitrobenzoic acid) (Ellman's reagent) is added to sulhydryl compounds. The chromophoric product resulting from Ellman's reagent with the reduced glutathione (2-nitro5-thiobenzoic acid) holds a molar absorption at $412 \mathrm{~nm}$ which is proportion to the level of reduced glutathione in the test sample. The glutathione peroxidase (GPx) was tested by the method of Rotruck et al. [33]. When this substance is mixed with reduced glutathione, its absorption shifts to a longer 
wavelength $340 \mathrm{~nm}$ and increase at this wavelength provides a direct measurement of the enzymatic reaction.

3.4. Histopathology of Tissues. Tissues were fixed in $10 \%$ formalin dehydrated in $95 \%$ ethanol and then cleared in xylene before embedded in paraffin. Sections (about $4 \mu \mathrm{m}$ ) were prepared and stained with hematoxylin and eosin (H\&E) dye and examined under a light microscope by a histopathologist who was ignorant of the treatment groups.

3.5. Statistical Analysis. All values were expressed as the mean \pm S.D. of five animals per group. Data were analyzed using one-way ANOVA followed by the Duncan multiple range test for analysis of biochemical data using SPSS (16.0). Values were considered statistically significant at $P<0.05$.

\section{Results}

4.1. Phytochemicals Investigation. It was found that ethanolic extract contained compounds known to have antioxidant activity like tannins, phlobatannins, flavonoids, anthocyanin, cardiac glycosides, and alkaloids (Table 1).

\subsection{Effects of Irvingia gabonensis Stem Bark on Body Weight} and Relative Weight of Organs of Cadmium-Induced Toxicity Rats. In Table 2 , there was significant increases $(P<0.05)$ in the relative weight of liver and heart of cadmium untreated rats when compared with the control, while treatment with Irvingia gabonensis stem bark (100 and $200 \mathrm{mg} / \mathrm{kg}$ ) significantly decreases the relative weight of heart and liver of cadmium-induced rats to values that are statistically similar $(P>0.05)$ to the control. All these changes induced by cadmium intoxication significantly $(P<0.05)$ was restored to near normal levels on administration of Irvingia gabonensis stem bark.

4.3. Effects of Irvingia gabonensis Stem Barkon Antioxidant Parameters and Marker Enzymes in Cadmium-Induced Toxicity in Rats. Administration of cadmium chloride significantly increased $(P<0.05)$ serum, hepatic, and cardiac lipid peroxidation (LPO) products measured as thiobarbituric acid reactive substances, respectively (Table 3 ). However, treatment with Irvingia gabonensis extract completely ameliorated cadmium chloride-induced increase in LPO. In cadmiuminduced rats, the activities of hepatic and cardiac GSH, SOD, and CAT as well as cardiac GPx decreased significantly relative to the control (Table 4). Excellent performance of extract at $(400 \mathrm{mg} / \mathrm{kg})$ reversed the adverse effect of cadmium chloride by normalizing the enzymatic antioxidant. Irvingia gabonensis pretreatment prior to cadmium exposure caused a significant increase in GPx activities as well as a noticeable increase in GSH level. In cadmium-induced rats, serum ALT and AST were significantly increased (Table 5 ) relative to the control. Treatment with Irvingia gabonensis before cadmium exposure resulted in significant protection of the liver and heart, as indicated by reductions in the elevated levels of ALT and AST; however, there was evidence of amelioration in the treated group.
TABLE 1: Phytochemical screening of ethanolic extract of Irvingia gabonensis stem bark.

\begin{tabular}{lc}
\hline Phytochemical & Extract content \\
\hline Alkaloids & +++ \\
Tannin & ++ \\
Phlobatannins & ++ \\
Saponin & + \\
Flavonoids & +++ \\
Anthraquinones & ++ \\
Phenol & +++ \\
Cardiac glycosides & ++ \\
\hline
\end{tabular}

$+=$ trace amount present $++=$ moderate amount present, and $+++=$ noticeable amount present.

4.4. Effects of Irvingia gabonensis Stem Bark on the Histology of Aorta and Liver. The histology of liver slide of cadmium untreated rats showed marked portal congestion, severe periportal cellular infiltration by mononuclear cells, and mild diffuse vacuolar degeneration of hepatocytes (Figure 1). The aorta from cadmium-induced toxicity rats revealed large focal area of myofibril necrosis with severe hemorrhages and fibrous connective tissue laid down (Figure 2). Treatment with ethanolic extract of stem bark Irvingia gabonensis (200 and $400 \mathrm{mg} / \mathrm{kg}$ ) reversed the adverse effect of cadmium toxicity on the histological architecture of the aorta and liver of the rats, which is similar to their control. The histological results further corroborated the biochemical findings suggesting the useful effects of Irvingia gabonensis stem bark in cadmiuminduced toxicity in rats.

\section{Discussion}

Cadmium is one of the main environmental and occupational pollutants in industrialized countries. Exposure to cadmium is linked with serious health hazards. Cadmium is a potent inducer of oxidative stress and affects cellular antioxidant defense potential biphasically by reserve and improvement of several antioxidant enzymatic and nonenzymatic molecules. The phytochemical study of Irvingia gabonensis stem bark extracts revealed the presence of polyphenol-rich compounds. Polyphenols have been suggested to decrease the oxidative stress in human. Flavonoids found in the extract may inhibit the oxidative stress by scavenging free radicals by acting as reducing agent, hydrogen atom donating molecules, or singlet oxygen quenchers, chelating metal ions and sparing other antioxidants (e.g., carotene, vitamins C and E) Fuhrman and Aviram [34]. Literature reveals that the carbonyl groups present in the flavonoids and phenolic compounds were responsible for antioxidant activity [35]. This investigation revealed that the Irvingia gabonensis contain pharmacologically active substance(s) such as alkaloids, glycosides, saponins, tannins, flavonoids, and phenolic compounds, which are responsible for the antioxidant activity.

In the present study, the potent chelation therapy of Irvingia gabonensis stem bark was examined against cadmiuminduced toxicity in the rats. The mean body weight of cadmium exposed group decreased with the increase in relative 
TABLE 2: Changes in the body weight and relative weight of organs of cadmium-induced toxicity rats treated with ethanolic extract of Irvingia gabonensis.

\begin{tabular}{lcccccc}
\hline \multirow{2}{*}{ Treatment } & \multicolumn{2}{c}{ Body weight $(\mathrm{g})$} & \multicolumn{2}{c}{ Weight of organs $(\mathrm{g})$} & \multicolumn{2}{c}{ Relative weight of organs } \\
& Initial & Final & Liver & Heart & Liver & Heart \\
\hline Control & $100.25 \pm 0.21$ & $117.46 \pm 5.32$ & $6.35 \pm 0.27$ & $0.51 \pm 0.02$ & $2.22 \pm 0.05$ & $0.22 \pm 0.04$ \\
Cadmium untreated & $112.08 \pm 1.12$ & $128.10 \pm 4.96$ & $5.24 \pm 0.60$ & $0.44 \pm 0.07$ & $3.35 \pm 0.08^{*}$ & $0.36 \pm 0.01^{*}$ \\
Cadmium $+200 \mathrm{mg} / \mathrm{kg}$ & $86.45 \pm 2.23$ & $125.55 \pm 3.11$ & $4.40 \pm 0.22$ & $0.31 \pm 0.03$ & $2.15 \pm 0.03^{* *}$ & $0.26 \pm 0.01^{* *}$ \\
Cadmium $+400 \mathrm{mg} / \mathrm{kg}$ & $98.02 \pm 3.35$ & $131.20 \pm 2.09$ & $5.34 \pm 0.40$ & $0.35 \pm 0.02$ & $2.24 \pm 0.03^{* *}$ & $0.24 \pm 0.03^{* *}$ \\
\hline
\end{tabular}

Values are means \pm s.e.m of 5 animals per group; cadmium = at $4 \mathrm{mg} / \mathrm{kg}$; cadmium treated = Irvingia gabonensis at $200 \mathrm{mg} / \mathrm{kg} ;$ cadmium treated = Irvingia gabonensis at $400 \mathrm{mg} / \mathrm{kg} ;{ }^{*}$ significantly different from control $(P<0.05) ;{ }^{* *}$ significantly different from cadmium untreated $(P<0.05)$.

TABLE 3: Changes in the levels of lipid peroxidation in cadmium-induced toxicity rats treated with ethanolic extract of Irvingia gabonensis.

\begin{tabular}{lccc}
\hline Treatments & Liver $(\mu \mathrm{mol} \mathrm{MDA} / \mathrm{mg}$ protein $)$ & Heart $(\mu \mathrm{mol} \mathrm{MDA} / \mathrm{mg}$ protein $)$ & Serum $(\mu \mathrm{mol} \mathrm{MDA} / \mathrm{mg}$ protein $)$ \\
\hline Control & $1.52 \pm 0.01$ & $2.05 \pm 0.02$ & $2.82 \pm 0.08$ \\
Cadmium untreated & $3.18 \pm 0.02^{*}$ & $4.11 \pm 0.03^{*}$ & $4.21 \pm 0.06^{*}$ \\
Cadmium $+200 \mathrm{mg} / \mathrm{kg}$ & $1.27 \pm 0.06^{* *}$ & $1.53 \pm 0.04^{* *}$ & $2.52 \pm 0.56^{* *}$ \\
Cadmium $+400 \mathrm{mg} / \mathrm{kg}$ & $1.46 \pm 0.05^{* *}$ & $1.85 \pm 0.02^{* *}$ & $2.04 \pm 0.35^{* *}$ \\
\hline
\end{tabular}

Values are means \pm s.e.m. of 5 animals per group; cadmium treated $=$ Irvingia gabonensis at $200 \mathrm{mg} / \mathrm{kg}$; cadmium treated = Irvingia gabonensis at $400 \mathrm{mg} / \mathrm{kg}$; ${ }^{*}$ significantly different from control $(P<0.05) ;{ }^{* *}$ significantly different from cadmium untreated $(P<0.05)$.

liver weight, which agrees with the findings of $[36,37]$ suggesting that prolonged exposure of cadmium indicates an increased risk of diabetes mellitus, which explains the weight loss in rats. Kaltreider et al. [38] reported that exposure to low heavy metals damages the glucocorticoid. The glucocorticoid hormones play a role in glucose control as well as carbohydrate, lipid, and protein metabolism.

Dysfunction in the glucocorticoid is linked to weight gain or loss. In cadmium rats treated with Irvingia gabonensis, the changed body weight and liver weight parameters recovered to near normal levels due to the antioxidant properties found in Irvingia gabonensis stem bark.

Lipid peroxidation is one of the main expressions of oxidative damage and is found to play an important role in the toxicity of cadmium [39]. Cadmium induced oxidative stress by producing hydroxyl radicals, superoxide anions, nitric oxide, and hydrogen peroxide [40,41]. Significant increase in the hepatic TBARS in cadmium intoxicated rats could be possibly due to excessive formation of free radicals which leads to changes in biological macromolecules [42]. Milton Prabu et al. [43] reported that lipid peroxidation is a sensitive marker of cadmium hepatotoxicity. In the present investigation cadmium intoxicated rats treated with Irvingia gabonensis showed a marked increase in the levels of MDA in the serum and tissues of rats when compared to controls. On the other hand, treatment with Irvingia gabonensis caused a significant decrease in the levels of MDA in these organs. This protective effect is due to the antioxidant potentials of Irvingia gabonensis, which decrease the oxidative damage by blocking free radicals produce and thus inhibiting lipid peroxidation. It has been shown in many studies that $\mathrm{Cd}$ induces oxidative damage by producing ROS $[6,44]$ and decreasing the biological activities of some antioxidant enzymes, such as SOD and CAT $[45,46]$ which play an important role in antioxidant profile and in scavenging of free radicals. The $\mathrm{Cd}$ has also been reported to cause damage to lipids by generating LPO $[18,47]$. This study also showed that exposure to Cd has led to an increase of LPO indicated by the elevation of TBARS levels, which is associated with a distinct decrease in the activity of the antioxidants SOD, CAT, and GSH in the liver and heart of the animals exposed to Cd. The SOD, CAT, and GSH are essential parts of cellular antioxidant defense system, and they play an essential role in protection against oxidative stress [48]. It has been proposed that $\mathrm{Cd}$ induces oxidative stress and LPO by depleting GSH, or by inhibition of antioxidant enzymes [48]. Moreover, Cd has been shown to exert a direct inhibitory effect on SOD and CAT activities via Cd-enzyme interaction with a resultant perturbation of enzyme topography critical for catalytic activity $[48,49]$. Our results showed that there was a marked increase of hepatic LPO, which is indicted by the elevation of the levels of $\mathrm{Cd}$ administration. This was consistent with other reports on Cdintoxicated rats [49]. The significant decrease in the activities of SOD and CAT in the livers and heart of the Cd groups compared to control groups may be attributed, in part, to an overwhelming oxidative modification of enzymatic proteins and biomembrane lipids by ROS, as evident by heightened level of LPO [49]. Well-known biomarkers of liver injury (ALT and AST) and histological changes were examined to evaluate the prophylactic effects of Irvingia gabonensis. Consistent with previous studies, our study confirmed that acute cadmium exposure damaged the liver, as shown by elevation of the serum aminotransferase activities and morphological changes observed in the liver sections [18, 47]. Interestingly, these adverse effects were significantly attenuated by Irvingia gabonensis in the treatment groups, which indicated a prominent hepatoprotective effect of Irvingia gabonensis against cadmium toxicity, similar to that reported on naringenin [47]. The increased levels of serum AST and ALT in cadmiuminduced rats indicate an increased permeability and damage 
TABLE 4: Changes in the levels of hepatic and cardiac antioxidant parameters in cadmium-induced rats treated with ethanolic extract of Irvingia gabonensis.

\begin{tabular}{|c|c|c|c|c|c|c|c|c|}
\hline \multirow{3}{*}{ Treatment } & \multicolumn{4}{|c|}{ Liver } & \multicolumn{4}{|c|}{ Heart } \\
\hline & GSH & GPx & SOD & CAT & GSH & GPx & SOD & CAT \\
\hline & \multicolumn{2}{|c|}{ (mg/g tissue) } & \multicolumn{2}{|c|}{ (U/mg protein) } & \multicolumn{2}{|c|}{ (mg/g tissue) } & \multicolumn{2}{|c|}{ (U/mg protein) } \\
\hline Control & $25.85 \pm 0.15$ & $35.55 \pm 0.83$ & $37.36 \pm 1.01$ & $35.57 \pm 1.08$ & $36.06 \pm 1.11$ & $45.74 \pm 5.74$ & $57.03 \pm 0.01$ & $9.37 \pm 0.81$ \\
\hline $\begin{array}{l}\text { Cadmium } \\
\text { untreated }\end{array}$ & $10.23 \pm 0.21^{*}$ & $14.65 \pm 0.41^{*}$ & $18.23 \pm 0.68^{*}$ & $20.22 \pm 0.58^{*}$ & $29.21 \pm 1.41^{*}$ & $25.26 \pm 1.10^{*}$ & $43.26 \pm 0.71^{*}$ & $5.57 \pm 0.31^{*}$ \\
\hline $\begin{array}{l}\text { Cadmium + } \\
200 \mathrm{mg} / \mathrm{kg}\end{array}$ & $23.33 \pm 0.24^{* *}$ & $34.23 \pm 0.45^{* *}$ & $35.88 \pm 0.03^{* *}$ & $32.89 \pm 0.41^{* *}$ & $34.65 \pm 2.14^{* *}$ & $37.02 \pm 1.44^{* *}$ & $54.16 \pm 0.37^{* *}$ & $7.22 \pm 0.36^{* *}$ \\
\hline $\begin{array}{l}\text { Cadmium + } \\
400 \mathrm{mg} / \mathrm{kg}\end{array}$ & $24.21 \pm 0.27^{* *}$ & $34.48 \pm 0.21^{* *}$ & $36.34 \pm 1.00^{* *}$ & $34.12 \pm 0.81^{* *}$ & $35.23 \pm 1.32^{* *}$ & $38.18 \pm 1.22^{* *}$ & $56.15 \pm 0.21^{* *}$ & $8.98 \pm 0.47^{* *}$ \\
\hline
\end{tabular}

Values are means \pm s.e.m. of 5 animals per group; cadmium treated = Irvingia gabonensis at $200 \mathrm{mg} / \mathrm{kg} ; \mathrm{cadmium}$ treated = Irvingia gabonensis at $400 \mathrm{mg} / \mathrm{kg}$; ${ }^{*}$ significantly different from control $(P<0.05) ;{ }^{* *}$ significantly different from cadmium untreated $(P<0.05)$.

TABLE 5: Changes in the activities of serum, hepatic, and cardiac alanine and aspartate aminotransferases in cadmium-induced rats treated with ethanolic extract of Irvingia gabonensis.

\begin{tabular}{|c|c|c|c|c|c|c|}
\hline \multirow{2}{*}{ Treatments } & \multicolumn{2}{|c|}{ Liver (U/L) } & \multicolumn{2}{|c|}{ Heart (U/L) } & \multicolumn{2}{|c|}{ Serum (U/L) } \\
\hline & AST & ALT & AST & ALT & AST & ALT \\
\hline Control & $57.80 \pm 3.42$ & $48.45 \pm 2.29$ & $48.45 \pm 0.02$ & $55.56 \pm 2.24$ & $4.54 \pm 1.77$ & $6.37 \pm 1.46$ \\
\hline Cadmium untreated & $28.74 \pm 2.62^{*}$ & $22.48 \pm 2.26^{*}$ & $26.22 \pm 2.38^{*}$ & $23.24 \pm 4.04^{*}$ & $8.39 \pm 0.56^{*}$ & $9.89 \pm 2.24^{*}$ \\
\hline Cadmium $+200 \mathrm{mg} / \mathrm{kg}$ & $42.56 \pm 1.88^{* *}$ & $38.10 \pm 1.12^{* *}$ & $39.02 \pm 1.25^{* *}$ & $39.12 \pm 1.24^{* *}$ & $4.13 \pm 1.50^{* *}$ & $5.78 \pm 1.38^{* *}$ \\
\hline Cadmium $+400 \mathrm{mg} / \mathrm{kg}$ & $51.32 \pm 0.34^{* *}$ & $44.01 \pm 1.05^{* *}$ & $42.02 \pm 1.45^{* *}$ & $47.12 \pm 1.02^{* *}$ & $4.01 \pm 1.42^{* *}$ & $6.01 \pm 1.28^{* *}$ \\
\hline
\end{tabular}

Values are means \pm s.e.m. of 5 animals per group; cadmium untreated $=$ at $50 \mathrm{mg} / \mathrm{kg}$; cadmium treated = Irvingia gabonensis at $200 \mathrm{mg} / \mathrm{kg} ; \mathrm{cadmium} \mathrm{treated} \mathrm{=}$ Irvingia gabonensis at $400 \mathrm{mg} / \mathrm{kg} ;{ }^{*}$ significantly different from control $(P<0.05) ;{ }^{* *}$ significantly different from cadmium untreated $(P<0.05)$.

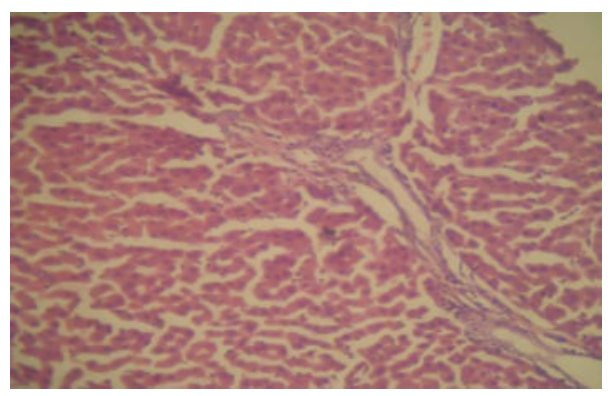

Control

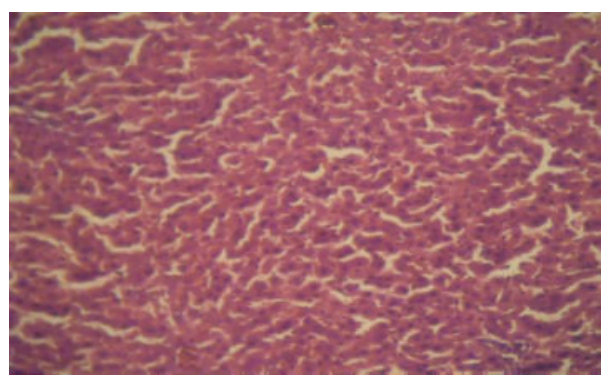

$\mathrm{Cd}+$ Irvingia gabonensis $(200 \mathrm{mg} / \mathrm{kg})$

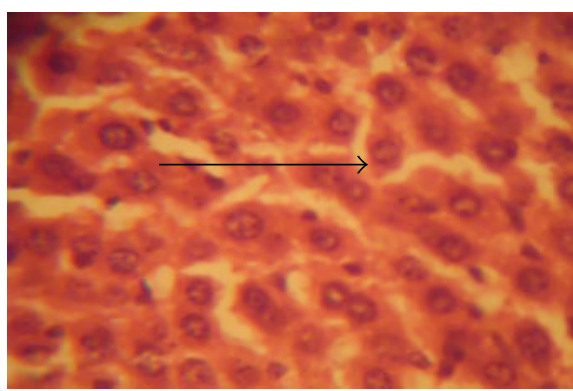

Cd

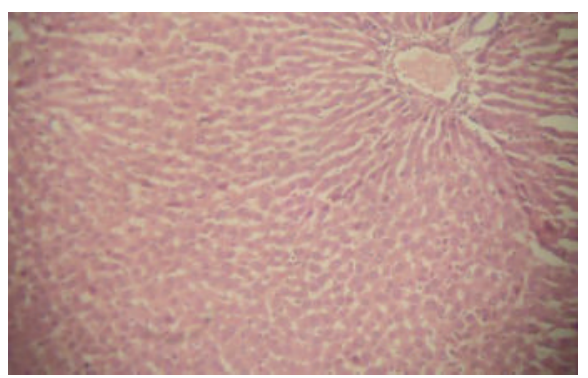

Cd + Irvingia gabonensis $(400 \mathrm{mg} / \mathrm{kg})$

Figure 1: Changes in histology of liver samples of Cadmium-induced toxicity in rats treated with Irvingia gabonensis ethanolic stem bark extract. Black arrows show mild periportal cellular infiltration by mononuclear cells. 


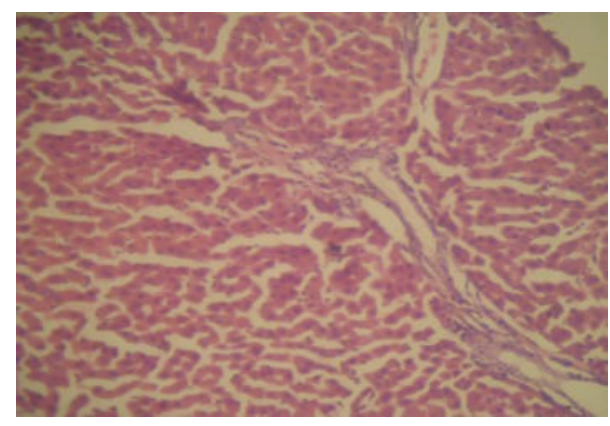

Control

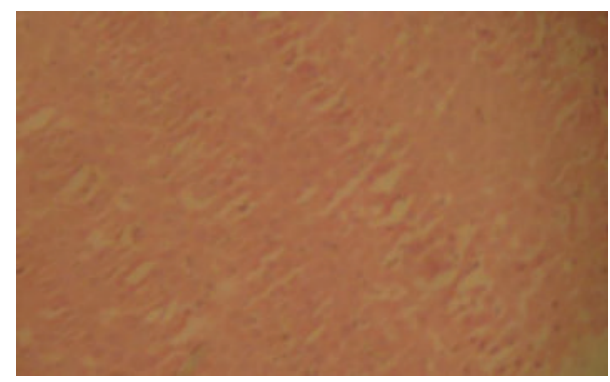

Cd + Irvingia gabonensis $(200 \mathrm{mg} / \mathrm{kg})$

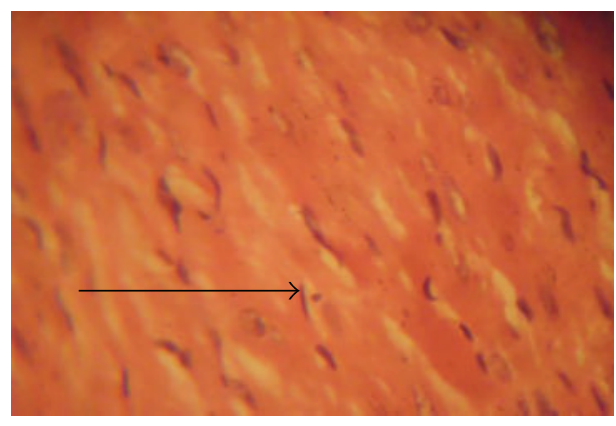

$\mathrm{Cd}$

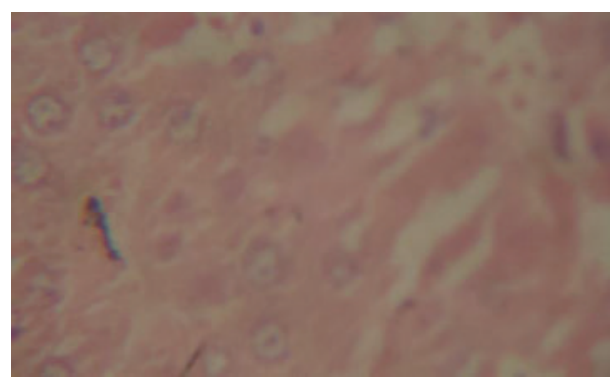

$\mathrm{Cd}+$ Irvingia gabonensis $(400 \mathrm{mg} / \mathrm{kg})$

FIGURE 2: Changes in histology of aorta from Cadmium-induced toxicity in rats treated with Irvingia gabonensis ethanolic stem bark extract. Black arrows show myofibril necrosis, severe hemorrhages, and fibrous connective tissue laid down.

and/or necrosis of hepatocytes. In our study, we found that extract of Irvingia gabonensis at a dose of $400 \mathrm{mg} / \mathrm{kg}$ caused a significant decrease in the activities of serum AST and ALT which further supports the beneficial effects of the extract of Irvingia gabonensis in cadmium-induced rats.

\section{Conclusion}

In conclusion, the results of the present study indicate that Irvingia gabonensis possess antioxidant and hepatoprotective properties, eliminating the deleterious effects of toxic metabolites from cadmium when administered orally. Further studies are required to identify the active component(s) and mechanism(s) underlying the beneficial effects of this plant.

\section{Ethical Approval}

Rats handling and treatments conform to guidelines of the National Institute of Health (NIH publication 85-23, 1985) for laboratory animal care and use. The ethical committee of the Afe Babalola University approved this study (ABUADSCI04/03/14/003). All animals in this study follow the institutional Animal Ethical Committee according to guidelines given by Committee for Control and Supervision of Experiments on animals (CPCSEA).

\section{Conflict of Interests}

The authors declare that they have no conflict of interests.

\section{Acknowledgment}

The authors wish to recognize the Department of Chemical Sciences, Biochemistry Unit, Afe Babalola University, AdoEkiti, where the research was conducted.

\section{References}

[1] P. Vinoth Kumar, A. Amala Bricey, V. Veera Thamari Selvi, C. Sudheer Kumar, and N. Ramesh, "Antioxidant effect of green tea extract in cadmium chloride intoxicated rats," Advances in Applied Science Research, vol. 1, no. 2, pp. 9-13, 2010.

[2] Z. Limei, L. Xiaoyong, C. Tongbin et al., "Regional assessment of cadmium pollution in agricultural lands and the potential health risk related to intensive mining activities: a case study in Chenzhou City, China," Journal of Environmental Sciences, vol. 20, no. 6, pp. 696-703, 2008.

[3] X.-Y. Liao, T.-B. Chen, H. Xie, and Y.-R. Liu, "Soil As contamination and its risk assessment in areas near the industrial districts of Chenzhou City, Southern China," Environment International, vol. 31, no. 6, pp. 791-798, 2005.

[4] S. Thijssen, J. Maringwa, C. Faes, I. Lambrichts, and E. van Kerkhove, "Chronic exposure of mice to environmentally relevant, low doses of cadmium leads to early renal damage, not predicted by blood or urine cadmium levels," Toxicology, vol. 229, no. 1-2, pp. 145-156, 2007.

[5] S. M. Alvarez, N. N. Gómez, L. Scardapane, M. W. Fornés, and M. S. Giménez, "Effects of chronic exposure to cadmium on prostate lipids and morphology," BioMetals, vol. 20, no. 5, pp. 727-741, 2007.

[6] J. Liu, S. Y. Qian, Q. Guo et al., "Cadmium generates reactive oxygen- and carbon-centered radical species in rats: insights 
from in vivo spin-trapping studies," Free Radical Biology and Medicine, vol. 45, no. 4, pp. 475-481, 2008.

[7] T. Jahangir, T. H. Khan, L. Prasad, and S. Sultana, "Alleviation of free radical mediated oxidative and genotoxic effects of cadmium by farnesol in Swiss albino mice," Redox Report, vol. 10, no. 6, pp. 303-310, 2005.

[8] V. Eybl, D. Kotyzová, L. Lešetický, M. Bludovská, and J. Koutenský, "The influence of curcumin and manganese complex of curcumin on cadmium-induced oxidative damage and trace elements status in tissues of mice," Journal of Applied Toxicology, vol. 26, no. 3, pp. 207-212, 2006.

[9] D. Swarup, R. Naresh, V. P. Varshney et al., "Changes in plasma hormones profile and liver function in cows naturally exposed to lead and cadmium around different industrial areas," Research in Veterinary Science, vol. 82, no. 1, pp. 16-21, 2007.

[10] M. Valko, H. Morris, and M. T. D. Cronin, "Metals, toxicity and oxidative stress," Current Medicinal Chemistry, vol. 12, no. 10, pp. 1161-1208, 2005.

[11] M. Abd-El-Baset and A. Abd El-reheem, “The roles of honeybee solution on the physiological parameters of rats exposed to cadmium chloride," Australian Journal of Basic and Applied Sciences, vol. 2, pp. 1438-1453, 2008.

[12] A. Abd-El-Reheem and S. Zaahkcuk, "Protective effect of Vitamin $\mathrm{C}$ and selenium against the toxicity induced by lead acetate on some physiological parameters in blood of male albino rats," Bulletin of the Physiological Society of Egypt, vol. 27, pp. 59-76, 2007.

[13] S. O. Asagba, G. E. Eriyamremu, M. A. Adaikpoh, and A. Ezeoma, "Levels of lipid peroxidation, superoxide dismutase, and $\mathrm{Na}+/ \mathrm{K}+$ ATPase in some tissues of rats exposed to a Nigerian-like diet and cadmium," Biological Trace Element Research, vol. 100, no. 1, pp. 75-86, 2004.

[14] B. I. Ognjanović, S. D. Marković, N. Z. Ethordević et al., "Cadmium-induced lipid peroxidation and changes in antioxidant defense system in the rat testes: protective role of coenzyme Q (10) and vitamin E," Reproductive Toxicology, vol. 29, pp. 191197, 2010.

[15] J. R. Lee, S. J. Park, H.-S. Lee et al., "Hepatoprotective activity of licorice water extract against Cadmium-induced toxicity in rats," Evidence-Based Complementary and Alternative Medicine, vol. 6, no. 2, pp. 195-201, 2009.

[16] E. Kowalczyk, A. Kopff, P. Fijałkowski et al., "Effect of anthocyanins on selected biochemical parameters in rats exposed to cadmium," Acta Biochimica Polonica, vol. 50, no. 2, pp. 543-548, 2003.

[17] J. L. Reyes, M. Lamas, D. Martin et al., "The renal segmental distribution of claudins changes with development," Kidney International, vol. 62, no. 2, pp. 476-487, 2002.

[18] A. S. El-Sharaky, A. A. Newairy, M. M. Badreldeen, S. M. Eweda, and S. A. Sheweita, "Protective role of selenium against renal toxicity induced by cadmium in rats," Toxicology, vol. 235, no. 3 , pp. 185-193, 2007.

[19] S. Satarug, S. H. Garrett, M. A. Sens, and D. A. Sens, "Cadmium, environmental exposure, and health outcomes," Environmental Health Perspectives, vol. 118, no. 2, pp. 182-190, 2010.

[20] R. E. Graham, A. C. Ahn, R. B. Davis, B. B. O'Connor, D. M. Eisenberg, and R. S. Phillips, "Use of complementary and alternative medical therapies among racial and ethnic minority adults: results from the 2002 national health interview survey," Journal of the National Medical Association, vol. 97, no. 4, pp. 535-545, 2005.
[21] E. Ernst, "When natural is not harmless," International Journal of Clinical Practice, vol. 60, no. 4, p. 380, 2006.

[22] A. A. Shati and F. G. Elsaid, "Effects of water extracts of thyme (Thymus vulgaris) and ginger (Zingiber officinale Roscoe) on alcohol abuse," Food and Chemical Toxicology, vol. 47, no. 8, pp. 1945-1949, 2009.

[23] T. J. Nangue, H. M. Womeni, F. T. Mbiapo, J. Fanni, and L. Michel, "Irvingia gabonensis fat: nutritional properties and effect of increasing amounts on the growth and lipid metabolism of young rats wistar sp," Lipids in Health and Disease, vol. 10, article 43, 2011.

[24] A. R. S. Dienagha and T. O. Miebi, "Energy requirments for cracking dika (Ogbono) nuts (Irvingia Gabonensis)," European Journal of Scientific Research, vol. 59, no. 2, pp. 208-215, 2011.

[25] R. Srinivasan, M. J. N. Chandrasekar, M. J. Nanjan, and B. Suresh, "Antioxidant activity of Caesalpinia digyna root," Journal of Ethnopharmacology, vol. 113, no. 2, pp. 284-291, 2007.

[26] O. H. Lowry, N. J. Rosebrough, A. L. Farr, and R. J. Randall, "Protein measurement with the Folin phenol reagent," The Journal of Biological Chemistry, vol. 193, no. 1, pp. 265-275, 1951.

[27] A. F. Mohun and I. J. Cook, "Simple methods for measuring serum levels of the glutamic-oxalacetic and glutamic-pyruvic transaminases in routine laboratories.," Journal of clinical pathology, vol. 10, no. 4, pp. 394-399, 1957.

[28] S. Reitman and S. Frankel, "A colorimetric method for the determination of serum glutamic oxalacetic and glutamic pyruvic transaminases," The American Journal of Clinical Pathology, vol. 28, no. 1, pp. 56-63, 1957.

[29] J. A. Buege and S. D. Aust, "Microsomal lipid peroxidation," Methods in Enzymology, vol. 52, no. C, pp. 302-310, 1978.

[30] J. M. McCord and I. Fridovich, "Superoxide dismutase. An enzymic function for erythrocuprein (hemocuprein)," Journal of Biological Chemistry, vol. 244, no. 22, pp. 6049-6055, 1969.

[31] H. Aebi, "Catalase estimation," in Methods of Enzymatic Analysis, H. V. Bergmeyer, Ed., pp. 673-684, Verlag Chemic, 1974.

[32] E. Beutler, O. Duron, and B. M. Kellin, "Improved method for the determination of blood glutathione," The Journal of Laboratory Clinical Medicine, vol. 61, pp. 882-888, 1963.

[33] J. T. Rotruck, A. L. Pope, H. E. Ganther, A. B. Swanson, D. G. Hafeman, and W. G. Hoekstra, "Selenium: biochemical role as a component of glatathione peroxidase," Science, vol. 179, no. 4073, pp. 588-590, 1973.

[34] B. Fuhrman and M. Aviram, "Flavonoids protect LDL from oxidation and attenuate atherosclerosis," Current Opinion in Lipidology, vol. 12, no. 1, pp. 41-48, 2001.

[35] T. Sajeesh, K. Arunachalam, and T. Parimelazhagan, "Antioxidant and antipyretic studies on Pothos scandens L," Asian Pacific Journal of Tropical Medicine, vol. 4, no. 11, pp. 889-899, 2011.

[36] F. M. El-Demerdash, M. I. Yousef, and F. M. E. Radwan, "Ameliorating effect of curcumin on sodium arsenite-induced oxidative damage and lipid peroxidation in different rat organs," Food and Chemical Toxicology, vol. 47, no. 1, pp. 249-254, 2009.

[37] M. Rahman, M. Tondel, and S. A. Ahmad, "Diabetes mellitus associated with arsenic exposure in Bangladesh," American Journal of Epidemiology, vol. 148, no. 2, pp. 198-203, 1998.

[38] R. C. Kaltreider, A. M. Davis, J. P. Lariviere, and J. W. Hamilton, "Arsenic alters the function of the glucocorticoid receptor as a transcription factor," Environmental Health Perspectives, vol. 109, no. 3, pp. 245-251, 2001.

[39] S. J. Stohs and D. Bagchi, "Oxidative mechanisms in the toxicity of metal ions," Free Radical Biology and Medicine, vol. 18, no. 2, pp. 321-336, 1995. 
[40] T. Koizumi and Z. G. Li, "Role of oxidative stress in single-dose, cadmium-induced testicular cancer," Journal of Toxicology and Environmental Health, vol. 37, no. 1, pp. 25-36, 1992.

[41] M. Waisberg, P. Joseph, B. Hale, and D. Beyersmann, "Molecular and cellular mechanisms of cadmium carcinogenesis," Toxicology, vol. 192, no. 2-3, pp. 95-117, 2003.

[42] S. J. Stohs, D. Bagchi, E. Hassoun, and M. Bagchi, "Oxidative mechanisms in the toxicity of chromium and cadmium ions," Journal of Environmental Pathology, Toxicology and Oncology, vol. 19, no. 3, pp. 201-213, 2000.

[43] S. Milton Prabu, J. Renugadevi, and T. Ramesh Kumar, "Ameliorative effect of selenium against cadmium induced biochemical alterations in Cirrhinus mrigala (Hamilton)," Asian Journal of Biosciences, vol. 2, pp. 143-148, 2007.

[44] L. Chen, L. Liu, and S. Huang, "Cadmium activates the mitogenactivated protein kinase (MAPK) pathway via induction of reactive oxygen species and inhibition of protein phosphatases 2A and 5," Free Radical Biology and Medicine, vol. 45, no. 7, pp. 1035-1044, 2008.

[45] C. O. Ikediobi, V. L. Badisa, L. T. Ayuk-Takem, L. M. Latinwo, and J. West, "Response of antioxidant enzymes and redox metabolites to cadmium-induced oxidative stress in CRL1439 normal rat liver cells.", International journal of molecular medicine, vol. 14, no. 1, pp. 87-92, 2004.

[46] M. Uchida, H. Teranishi, K. Aoshima, T. Katoh, M. Kasuya, and H. Inadera, "Reduction of erythrocyte catalase and superoxide dismutase activities in male inhabitants of a cadmium-polluted area in Jinzu river basin, Japan," Toxicology Letters, vol. 151, no. 3, pp. 451-457, 2004.

[47] J. Renugadevi and S. M. Prabu, "Cadmium-induced hepatotoxicity in rats and the protective effect of naringenin," Experimental and Toxicologic Pathology, vol. 62, no. 2, pp. 171-181, 2010.

[48] I. Messaoudi, J. El Heni, F. Hammouda, K. Saïd, and A. Kerkeni, "Protective effects of selenium, zinc, or their combination on cadmium-induced oxidative stress in rat kidney," Biological Trace Element Research, vol. 130, no. 2, pp. 152-161, 2009.

[49] E. Casalino, G. Calzaretti, C. Sblano, and C. Landriscina, "Molecular inhibitory mechanisms of antioxidant enzymes in rat liver and kidney by cadmium," Toxicology, vol. 179, no. 1-2, pp. 37-50, 2002. 

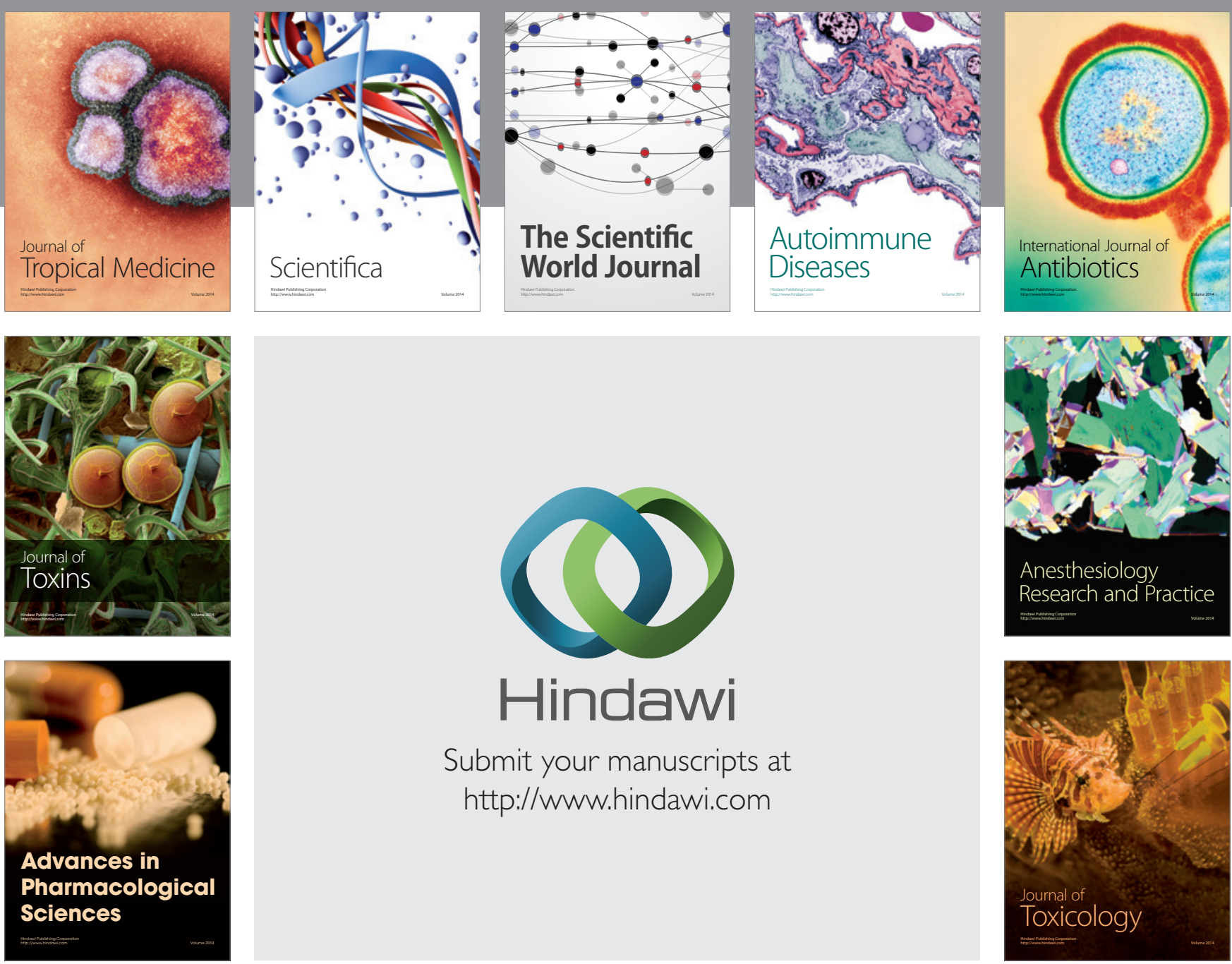

\section{Hindawi}

Submit your manuscripts at

http://www.hindawi.com
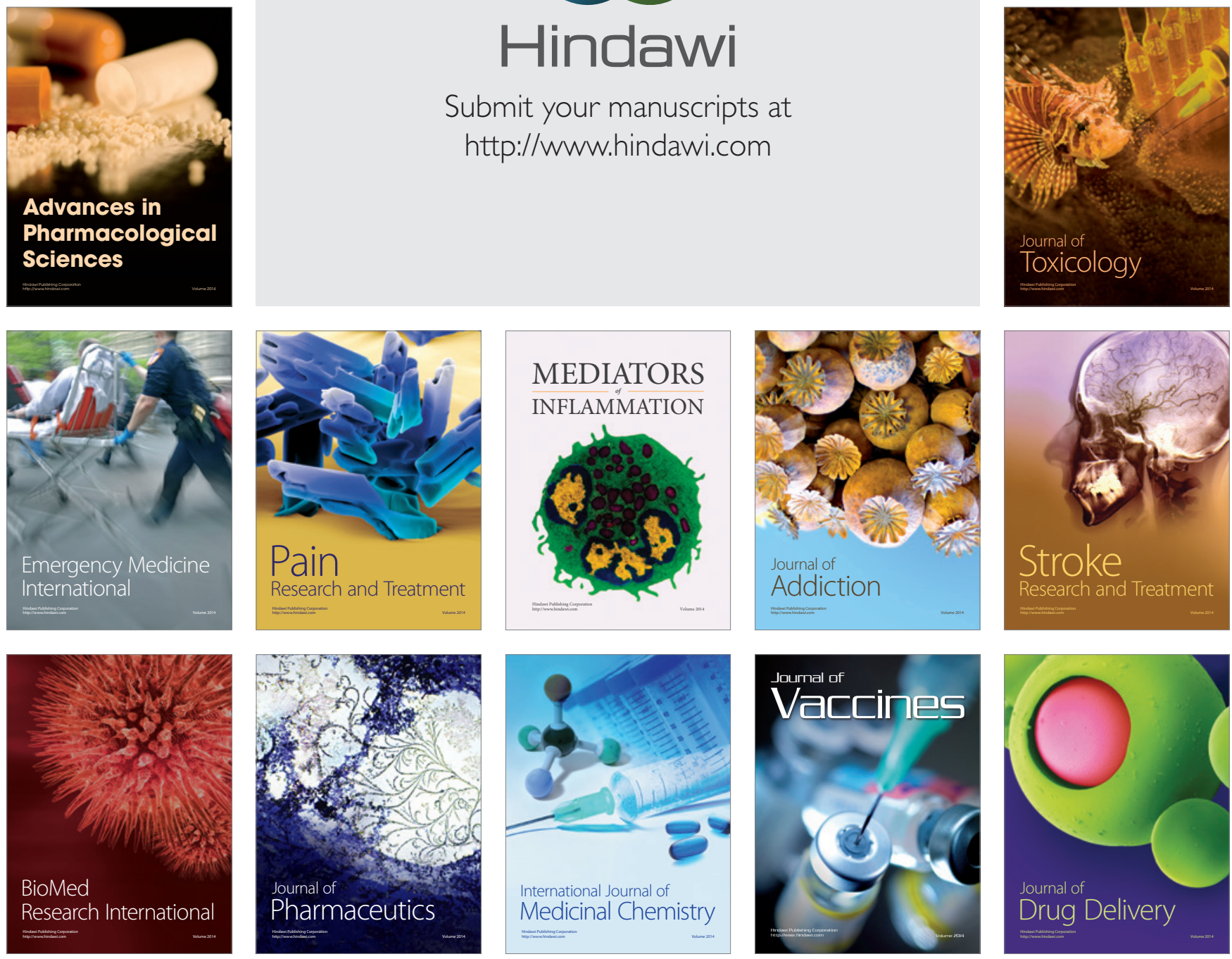